\title{
Ativismo, decisão judicial e fundamentação irracional: uma proposta de controle
}

\author{
Activism, judicial decision and irrational grounding: a control proposal
}

\author{
Nestor Eduardo Araruna Santiago* \\ Ruth Araújo Viana*
}

\section{Resumo}

O objetivo do artigo é identificar se a fundamentação irracional é causa para a anulação de decisões judiciais. Reforçar o dever institucional do julgador de decidir racionalmente e, portanto, alicerçado nas provas do processo e no ordenamento jurídico, é um compromisso com o Estado Democrático de Direito que não pode ser esquecido. Nesse sentido, será estudado como o ativismo judicial compromete a função institucional do Poder Judiciário, atingindo diretamente a imparcialidade do julgador. Para a produção deste trabalho científico será utilizado o método hipotético-dedutivo e estudos de casos. $\mathrm{E}$ a partir disso, tem-se a compreensão sobre o ativismo judicial e o dever de imparcialidade procedimental do juízo para justificar a necessidade de controle de decisões judiciais cujos fundamentos fogem da prova produzida no processo ou vão de encontro aos dispositivos legais. O método para o controle da decisão judicial ativista será, portanto, identificar os fundamentos expostos nas decisões que estejam alheios às provas produzidas nos autos e sem qualquer respaldo legal.

Palavras-chave: Ativismo Judicial. Fundamentação. Imparcialidade. Poder Judiciário.

\section{Abstract}

The objective of the article is to identify whether the irrational grounding is the cause for the annulment of judicial decisions. It is important to reinforce the institutional duty of the judge to decide rationally and, therefore, based on the evidence of the procedure, on the legal system, and to the commitment to the Democratic Rule of Law. In this sense, we will study how judicial activism compromises the institutional function of the Judiciary branch, directly affecting the impartiality of the judge. To realize this scientific study, we use the hypothetical-deductive method and case studies. Based on this, understanding judicial activism and the duty of procedural impartiality of the court to justify the need to control judicial decisions whose foundations are beyond the evidence produced in the process or to go against legal provisions. The method for the activist judicial decision control will be, therefore, to identify the grounds exposed in the decisions which are unrelated to the evidence produced in the records and without any legal support.

Keywords: Judicial Activism. Grounding. Impartiality. Judiciary Branch.

Doutor em Direito Tributário (2005), com estágio Pós-Doutoral em Direito pela Universidade do Minho, Portugal (2016); Mestre (2000) e Especialista (2000) em Ciências Penais pela Universidade Federal de Minas Gerais (UFMG). Professor Titular do Programa de PósGraduação Stricto Sensu em Direito Constitucional e do Curso de Graduação em Direito da Universidade de Fortaleza (UNIFOR), onde ministra a disciplina Processo, Garantismo e Estado Democrático de Direito (PPGD) e Direito Processual I (Graduação). Líder do Grupo de Pesquisa Tutela Penal e Processual Penal dos Direitos e Garantias Fundamentais (Unifor), vinculado ao Laboratório de Ciências Criminais (LACRIM - Unifor), realizando pesquisas empíricas que envolvem o Direito Penal, o Processo Penal e as relações entre políticas públicas e processo. Professor Adjunto IV do Curso de Graduação em Direito da Universidade Federal do Ceará (UFC), onde ministra as disciplinas Direito Processual Penal I e II. Atua nas áreas de Direito Processual Penal e Direito Penal, com interfaces para o garantismo e o ativismo. Advogado Criminalista. E-mail: nestorsantiago@unifor.br

Juíza do Estado do Rio Grande do Norte. Promotora de Justiça no Estado do Tocantins (2014-2020). Doutoranda em Direito Constitucional pela Universidade de Fortaleza (2018 até a presente data). Mestra pelo Curso de Direito Constitucional na Universidade de Fortaleza no Ceará (2012). Membro colaborador da ENFAM - Escola Nacional de Formação e Aperfeiçoamento de Magistrados do STJ (Superior Tribunal de Justiça). Professora da Pós-Graduação da Uni7 (Centro Universitário 7 de Setembro) e do Curso Preparatório para Concursos Públicos THEMAS. Especialista em Direito Penal e Processo Penal pela Faculdade Entre Rios Piauí (2012). Especialista em Direito Constitucional pela Faculdade Entre Rios Piauí (2014); Especialista em Estado de Direito e Combate à Corrupção pela Escola Superior da Magistratura Tocantinense (2017). Graduada em Direito pela Universidade de Fortaleza (2010). Tem experiência na área Penal, Processo Penal, Direito Constitucional e Direito Administrativo. Trabalhou como professora na Universidade de Fortaleza - Unifor, atuando na Pós-Graduação e Graduação. Possui conhecimento nas línguas estrangeiras: inglês (ESOL), espanhol (básico) e francês (básico). É Autora de obras jurídicas e palestrante. E-mail:ruthinhaviana@hotmail.com 


\section{Introdução}

O Poder Judiciário, por meio da Constituição Federal de 2018 (CF), vem integrando um papel cada vez mais ativo socialmente. A essência democrática do Poder Judiciário apresenta-se mais visível à sociedade brasileira e, no mesmo passo, há um alargamento do exercício deste poder para a satisfação de anseios populares sob a justificativa de fazer justiça e captar o sentimento da sociedade. Tal essência, no entanto, nem sempre é tida com base em fundamentos encontrados nos autos processuais, o que pode ser considerado uma manifestação do ativismo judicial.

O presente artigo científico visa expor o ativismo judicial como um problema a ser enfrentado pelo Poder Judiciário para o cumprimento das suas finalidades institucionais, ao passo que compromete a subsunção aos regramentos constitucionais e causa desequilíbrio na harmonia dos poderes, afetando a democracia.

O tema é extremamente relevante, pois apesar de exaustivamente debatido pela doutrina, ainda detém uma conotação muito abstrata sobre o método que pode ser utilizado para o controle decisões judiciais ativistas, carecendo de efetividade.

Assim, dada a relevância do debate a respeito do ativismo judicial e da necessidade de controle das decisões irracionais, pergunta-se: o juiz, ao decidir com base em fatores não legais e não provados nos autos, está agindo de maneira parcial ativista e, com isso, dando ensejo a anulabilidade da decisão?

O objetivo geral do artigo, portanto, é identificar se a decisão irracional é causa para a anulação de decisões judiciais. Para isso será analisado o uso de argumentos irracionais como fundamentos de justificação e decisão judicial sob o critério de fazer o que é certo ou justo, para fins de verificação sobre a possibilidade de a motivação vincular o decidir do juízo como prova de sua parcialidade para o caso.

Como objetivos específicos, serão verificados se decisões judiciais ativistas podem e devem ser controladas para evitar julgamentos casuísticos, com base no arcabouço legal e sustentação nas provas elaboradas no processo para o decidir do juízo, de modo a expor decisão racional e argumentativa, devidamente fundamentada.

Na primeira seção do artigo será apresentado o conceito de ativismo judicial; após, será abordado o dever de imparcialidade do juízo para posteriormente justificar como o ativismo judicial compromete a parcialidade do julgador. Por fim, será aferido se decisões que usam como justificativas para o julgar dos fundamentos de cunho social, político, cultural não provadas no processo e contrárias ao ordenamento jurídico são decisões ativistas que merecem ser reformadas. Em outras palavras, busca-se aferir se a decisão ativista do julgador compromete sua imparcialidade no processo.

Trata-se de pesquisa qualitativa, realizada por meio de método dedutivo e de procedimento técnico bibliográfico e documental. $O$ artigo conseguirá apresentar a proposta do controle do ativismo judicial através da apresentação de casos concretos em que o Poder Judiciário exerceu ativismo tendo a possibilidade desse método ser reproduzido em qualquer outra decisão judicial para fins de controle do ativismo judicial.

\section{Um conceito de ativismo judicial}

Segundo Barboza (2007), o Poder Judiciário representa, para a sociedade, a possibilidade de concretização da justiça. Assim, na medida em que os direitos fundamentais previstos na CF não são efetivados, as partes solicitam ao juiz o seu reconhecimento. Neste contexto, Garapon (2001)afirma que a partir da segunda metade do século XX surgiu o fenômeno da constitucionalização das garantias processuais. Neste sentido, enquanto a judicialização é um fenômeno social, para Castro (2016) o ativismo judicial apresenta-se na Contemporaneidade como uma postura judicial diante de um caso em concreto.

Ocorre que o juiz, por mais que seja capacitado juridicamente, nunca será neutro aos fatos sociais, pois a sociedade reage de forma diferente a respeito de cada um, ao passo que o ser humano também se expressa de forma única no agir social. Assim, cada caso é um caso: em determinadas situações, considerando uma identidade de fatos, a decisão judicial de um caso pode apresentar ter sido feito "justiça", enquanto para outro, não. São várias as razões subjetivas que se buscam padronizar através da norma da atuação do conteúdo do justo e assim evitar que as concepções de vida de cada um introduzam a ideia falsa de justiça. Por essa razão, Hobbes (2012) argumenta que os homens quando restringem a si, configurando o Estado, na verdade, querem impor limites à parcialidade humana. 
Nesta ordem de ideias, pode-se afirmar que o direito visa coordenar as relações em sociedade, ao passo que o ativismo judicial ${ }^{1}$ é uma forma de burlar o direito amparado na falsa pretensão de o juiz "fazer justiça". Por este motivo Habermas (1997) já apresenta a necessidade de o juiz ser capaz de superar a filosofia da consciência para trabalhar com a lei que o orienta a regular fatos sociais. Segundo Ferrajoli (2018), no Estado pós-moderno, o ativismo judicial representa uma crise da democracia estabelecida.

Apesar de inúmeras conceituações diferentes de ativismo judicial na doutrina brasileira² ${ }^{2}$ é necessário que se entenda o ativismo judicial como a forma de pronunciamento jurídico baseado em aspectos pessoais e sociais que diferem do conteúdo jurídico apresentado pelas partes e do conteúdo normativo da Constituição Federal ao qual o juízo é vinculado, exprimindo verdadeira supressão ou afastamento da lei emanada do Poder Legislativo e adoção de postura de criação legislativa pelo Poder Judiciário para o caso em concreto.

Discorrer sobre ativismo judicial tem como enfoque entender os limites do poder de decisão judicial, colocando como referência, consequentemente, o Poder Judiciário para análise do bom uso do poder que lhe é conferido e se este corresponde aos ditames da ordem constitucional e democrática brasileira. (KOERNER, 2013).

Não se afasta a possibilidade de interpretação da norma pelo juiz, muito menos a possibilidade de se utilizar de argumentação jurídica para melhor julgar um caso concreto; o que se busca é afastar a chance de o juiz, convencido de que a norma é injusta, refutá-la em todo ou em parte do caso, criando, literalmente, uma terceira norma com fundamentos solipsistas ${ }^{3}$.

Entender o que o ativismo judicial representa em essência é crucial para que se possa abordar criticamente a necessidade de controle de decisões ativistas, evitando-se o casuísmo e as incoerências de julgamentos, bem como a interferência ilegítima do Poder Judiciário na iniciativa de criação de lei por parte do Poder Legislativo.

Da mesma forma, é necessário compreender que o ativismo judicial não se amolda à concepção de atuação ativa do juízo quando não há lei formalmente posta para regular casos concretos, pois, nestes casos, será imprescindível que o juiz se utilize de outras fontes do direito para apresentar uma solução ao problema existente nos moldes da orientação finalística da CF.

A inafastabilidade do Poder Judiciário para apreciação de fatos que possam lesionar ou ameaçar direitos é um verdadeiro propulsor da liberdade criativa do juízo, desde que fundamentada na Constituição Federal, para que seja possível a concretização da justiça pelo direito. Já se parte do pressuposto que o ativismo judicial é a expressão de coerção pelo decidir do Poder Judiciário não provado nos autos, indo de encontro aos ditames das normas constitucionais vigentes e declarando, consequentemente, que toda decisão ativista é juridicamente irracional.

\section{Dever de imparcialidade judicial}

A neutralidade do juízo não é exigida para a aplicação do direito. Mesmo que se decida, amparado pela lei, o juiz, por se tratar de um ser humano, sempre estará imbuído de suas convicções morais, filosóficas, religiosas, além de sua experiência de vida, entre outros fatores influenciadores do seu caráter e personalidade.

A imparcialidade, por sua vez, é um critério jurídico, baseado nas normas constitucionais e processuais para que o julgador possa exercer a função de julgar. A decisão do magistrado somente é adequada quando há a preservação da imparcialidade, ou seja, quando os critérios subjetivos não interferem de forma objetiva no teor da decisão. A objetividade é aferida através do uso das provas produzidas nos autos que garantem a fundamentação

Foi nos Estados Unidos que se deu origem ao ativismo judicial, sendo a decisão de Lochner v. New York, 198 U.S. 45 (1905) o caso de maior representatividade deste fenômeno.

2 Ao contrário do que defende Luís Roberto Barroso (2009), Ministro do Supremo Tribunal Federal, o ativismo será trabalhado como uma forma de criação livre do direito justificado sob o espectro falso de fazer justiça pelo Poder Judiciário. Da mesma forma, o ativismo judicial também não será expresso em graus conforme leciona Nagibe de Melo Jorge (2014). Em outras palavras, não se afirmará que quanto mais os juízes se atenham ao significado literal do texto normativo, menos ativistas serão e quanto mais livres se considerem para interpretar o texto normativo, trazendo-lhe significados novos e até argumentos extrajurídicos, desvinculando-se da letra da lei, mais ativistas serão. O ativismo judicial é entendido como simples e puro decidir contra o ordenamento jurídico constitucional não amparado em provas construídas ao longo do processo.

3 Streck (2013, on line) afirma que deslocar o problema da atribuição de sentido para a consciência é apostar em plena era do predomínio da linguagem no individualismo do sujeito que "constrói" o seu próprio objeto de conhecimento. Pensar assim é acreditar que o conhecimento deve estar fundado em estados de experiência interiores e pessoais, não se conseguindo estabelecer uma relação direta entre esses estados e o conhecimento objetivo de algo para além deles. Segundo ele, essa problemática afetou o Poder Judiciário, pois os julgadores, por vezes, deixam "claro" que estão julgando "de acordo com a sua consciência" ou o "seu entendimento pessoal sobre o sentido da lei". Essa questão aparece teorizada sob o manto do poder discricionário dos juízes. 
racional do decidir ${ }^{4}$. A discricionariedade do juiz existe dentro da lei e das provas produzidas no processo. No momento em que o ato decisório é devidamente fundamentado, as motivações do juízo tornam-se parâmetros legítimos para o decidir, evitando, através da fundamentação, que as partes fiquem à mercê do juízo moral do julgador. Nessas condições, o dever de motivar cumpre o papel de legitimar as pré-compreensões do juízo, (MARQUES, 2016), permitindo que a subjetividade se afirme sobre a realidade objetiva do processo. Por conseguinte, às partes se garante o devido processo legal de modo substancial, excluindo ou diminuindo as chances de terem uma decisão moral do julgador aplicada ao caso concreto.

Falar de neutralidade e imparcialidade do juízo parece ser óbvio e intrínseco ao devido processo legal. Contudo, neste momento, é importante estudar essas características para que se possa trabalhar com as repercussões geradas sobre o ativismo judicial. É necessário fazer um destaque entre a aproximação conceitual e prática da neutralidade e da imparcialidade pelo juízo, pois o juiz, muitas vezes, pode se julgar imparcial para decidir um determinado caso, mas em sua essência humana não o é completamente neutro ao processo, apresentando uma tendência para a confirmação ou não de um direito em razão de sua experiência e concepção de vida. Observa-se que neutralidade e imparcialidade, embora tenham conceitos e aplicações distintas, podem apresentar pontos convergentes.

O grande problema entre a imparcialidade e a neutralidade reside na dificuldade de o juiz entender que estas concepções exigem um processo reflexivo sobre o decidir. Ser imparcial significa ter interesse em presidir e julgar o processo, mas sem antever o resultado de sua decisão ou sem buscar orientar o seu decidir antes da formação das provas processuais, utilizando-se ou não do arcabouço normativo. Ser imparcial exige a utilização de uma técnica de desapego infinita a julgamentos pré-definidos, pois por maior que seja a similaridade entre os casos, eles sempre serão únicos em essência. Por essa razão é que o ato de refletir antes de decidir e fundamentar o decidir é tão importante para a preservação da imparcialidade judicial. Assim, a constitucionalização das garantias processuais deve ser protegida também pelo julgador ao decidir o caso em concreto. (PICÓ Y JUNOY, 2012).

Veja-se que exigir do juiz o entendimento de seu interior humano, ao ponto de saber discernir se está apto ou não para o julgamento de um processo, demanda uma compreensão psicológica do ser que não será possível abordar cientificamente neste artigo. Contudo, no momento em que o juiz expressa em sua decisão motivos externos à prova produzida no processo para justificá-la, que não são capazes de serem trazidos aos autos como elementos de prova processual e que se apoiam em concepções morais, filosóficas, políticas, sociais, é possível afirmar que o juiz teve sua imparcialidade comprometida.

O papel do juiz no Estado Democrático de Direito é promover direitos fundamentais, porém, nessa aproximação do direito com a política, houve uma confusão sobre o decidir, gerando decisões mais políticas do que jurídicas. (OLIVEIRA NETO, 2011) Deve-se compreender que o compromisso que o magistrado tem para com a sociedade se dá por meio do cumprimento das normas e não pela satisfação de sentimentos que por acaso sejam por ele captados e veiculados por meio de decisões judiciais.

Costa (2013) afirma que a imparcialidade do juízo é o primeiro critério de validade para o julgamento do direito, pois sem ela nunca existirá devido processo legal. Assim, é obvio que não se pode exigir que um juiz seja neutro em seu decidir, no entanto, caso sua não neutralidade ganhe contornos externos por estar escrita como forma de motivação da sentença, sendo, então, capaz de refletir em oscilações do decidir imparcial, é imperioso que se proceda a um novo julgamento do caso, e, preferencialmente, por outro magistrado.

O vislumbre da imparcialidade do juízo, por exposição de fundamentos solipsistas, vincula o dispositivo da sentença mesmo que apoiado em outros fundamentos jurídicos para o decidir, pois não há mais como se ter certeza, a partir da expressão de um motivo não amparado no sistema jurídico, que o juízo decidiu com base em motivações legais sem que a imparcialidade do juízo tenha sido comprometida.

Isso porque o juízo pode ter se utilizado do arcabouço jurídico para justificar ilegitimamente o decidir, ou seja, antes ou durante a construção das provas já havia formulado uma decisão jurídica para o caso. Neste sentido, resta comprovado, portanto, que a neutralidade do juízo atingiu a sua imparcialidade. $O$ indício da subjetividade do

\footnotetext{
A Teoria do Livre Convencimento Motivado é utilizada no Brasil, embora sem amparo constitucional, pois apesar de ser obrigatória a fundamentação, não se vislumbra na Constituição Federal que esta fundamentação seja livre (Art. 93, IX da CF). A liberdade no convencimento do julgador nunca foi ilimitada, pois sempre deve obediência a prova produzida nos autos e vincula-se aos comandos constitucionais do devido processo legal. Assim, a Teoria do Livre Convencimento Motivado, embora com nomenclatura declare que o juiz pode decidir da maneira que lhe convier desde que fundamente o decidir não é acertada (RODRIGUES, 2017). Seguir esta lógica de raciocínio é defender o livre convencimento motivado como uma permissão para que o juiz estabeleça sua verdade sobre os fatos pela escolha livre das provas, deturpando o garantismo processual, e, assim, consequentemente, autorizando julgamentos contrários aos ditames constitucionais do devido processo legal. Por essa razão, valem as críticas de Lenio Streck à expressão "livre convencimento motivado", que não tem amparo constitucional (STRECK, 2013).
} 
juízo na aplicação da lei abala a imparcialidade necessária ao apoio democrático da decisão judicial, fazendo-se necessário que a decisão avençada seja reformada pela via impugnativa própria.

\section{0 ativismo judicial como expressão da parcialidade do juízo}

Bonavides (2004) afirma que o crescimento exponencial da relevância da jurisdição constitucional reside no fato de ser o Poder Judiciário, na prática, capaz de concretizar o direito, conferindo segurança jurídica sobre a imperiosidade da norma e garantia de direitos fundamentais. Neste sentido, a justiça constitucional se tornou uma premissa da democracia: a democracia jurídica e a democracia com legitimidade.

Ao Poder Judiciário compete aplicar o direito consubstanciado nas normas positivadas pela CF e nas leis esparsas por ela recepcionadas. Da mesma forma, cabe ao órgão jurisdicional integrar, interpretar e argumentar o direito seguindo os comandos e orientações que estão expressos na CF.

Necessariamente, o Poder Judiciário se vincula às provas produzidas nos autos e aos dispositivos normativos, constitucionais ou não, para decidir. ${ }^{5}$ Caso o Judiciário se ocupe de justificar irracionalmente suas decisões, ou seja, decidir contrariamente às normas e/ou às provas produzidas nos autos, cria-se uma incerteza jurídica acerca da capacidade de imparcialidade do julgador para o processo.

Em demonstração de um ativismo judicial que contrariou expressamente o comando legal, a Apelação n. 70073021917 do Tribunal de Justiça do Rio Grande do Sul (TJRS), julgada em 27 de setembro de 2017, deu provimento ao recurso de apelação do denunciado para absolvê-lo da conduta de crime de estupro de vulnerável, relativizando a vulnerabilidade prevista no Art. 217-A do Código Penal ${ }^{6}$. Sustentaram os julgadores que embora não se desconheça que os Tribunais Superiores firmaram entendimento no sentido de que a presunção de violência, no caso de abuso sexual, praticado contra vítima de idade igual ou inferior a quatorze anos não é passível de relativização. Neste caso, a absolvição do acusado é imperativa, haja vista que a vítima, quando ouvida em juízo, disse que já não era mais virgem e, segundo os fundamentos da decisão, apresentava o necessário discernimento para consentir com a prática realizada, não se encontrando, dessa maneira, em estado de vulnerabilidade a atrair a regra do Artigo 217-A do Código Penal.

É óbvio, mas parece ser necessário ter que reafirmar as palavras de Abboud e Lunelli (2015, p. 21), que "viver em um Estado de Direito significa que ninguém, nem mesmo um juiz, tem o direito de ignorar os textos legais". Neste sentido, esclarece Nunes (2011) que o órgão jurisdicional exerce sua função sobre as consequências do não cumprimento das normas e não sobre as causas, pelo menos, na maioria das vezes. A incerteza do pronunciamento judicial tendo como base a discricionariedade irracional é um ativismo não passível de controle. Contudo, nenhum poder pode agir sem que seja possível o controle de suas decisões.

No Habeas Corpus 124.306/RJ ${ }^{7}$, a $1^{\text {a }}$ turma do Supremo Tribunal Federal fundamentou sua decisão para revogação da prisão preventiva com base em aspectos não inerentes ao processo. O primeiro objeto de crítica

5 Não se busca neste artigo esgotar o que se entende por provas ou limitá-las a compreensões diretas dos fatos, pois a prova pode ser produzida de diversas maneiras e pode, conjuntamente, com os indícios, direcionar racionalmente a decisão do julgador.

6 Apelação Crime. Estupro De Vulnerável. Relativização Da Vulnerabilidade. No que se consta, a vítima possuía, ao tempo do fato, menos de 14 anos de idade. Assim, é perceptível, na declaração judicial, sua plena capacidade de entendimento sobre seus atos, além da conjunção carnal ter se dado com o seu consentimento, o que relativiza sua vulnerabilidade. Constata-se que o réu é um jovem, sem antecedentes criminais, que estava abalado psicologicamente em razão do aborto sofrido por sua esposa, quando se envolveu com sua cunhada. Deste envolvimento clandestino gerou-se uma suposta filha, registrada e criada pelo agente com muito amor. Além disso, há o fato da incerteza sobre a real paternidade da criança por parte da ofendida, uma vez que não foi apresentado o exame de DNA O caso dos autos não retrata, exatamente, uma situação de abuso sexual, mas de precocidade e, como tal, seria uma hipocrisia impor pesada pena ao denunciado, quando há na mídia e, principalmente nas novelas, filmes, seriados e programas de televisão, todo um estímulo à sexualidade, fazendo que, cada vez mais cedo as meninas despertem para essa realidade. RÉU absolvido. Apelação provida - ACR 70073021917 RS).

7 Ementa: Direito Processual Penal. Habeas Corpus. Prisão preventiva. Ausência dos requisitos para sua decretação. Inconstitucionalidade da incidência do tipo penal do aborto no caso de interrupção voluntária da gestação no primeiro trimestre. Ordem concedida de ofício. 1 . O Habeas Corpus não é cabível na hipótese. Todavia, é o caso de concessão da ordem de ofício, para o fim de desconstituir a prisão preventiva, com base em duas ordens de fundamentos. 2. Em primeiro lugar, não estão presentes os requisitos que legitimam a prisão cautelar, a saber: risco para a ordem pública, a ordem econômica, a instrução criminal ou a aplicação da lei penal (CPP, Art. 312). Os acusados são primários e com bons antecedentes, têm trabalho e residência fixa, e têm comparecido aos atos de instrução, além da promessa em se cumprir pena em regime aberto, na hipótese de condenação. 3. Em segundo lugar, é preciso conferir interpretação conforme a Constituição aos próprios Arts. 124 a 126 do Código Penal que tipificam o crime de aborto - para excluir do seu âmbito de incidência a interrupção voluntária da gestação efetivada no primeiro trimestre. A criminalização, nessa hipótese, viola diversos direitos fundamentais da mulher, bem como o princípio da proporcionalidade. 4 . A criminalização é incompatível com os seguintes direitos fundamentais: os direitos sexuais e reprodutivos da mulher, que não pode ser obrigada pelo Estado a manter uma gestação indesejada; a autonomia da mulher, que deve conservar o direito de fazer suas escolhas existenciais; a integridade física e psíquica da gestante, que é quem sofre, no seu corpo e no seu psiquismo, os efeitos da gravidez; e a igualdade da mulher, já que homens não engravidam e, portanto, a equiparação plena de gênero depende de se respeitar a vontade da mulher nessa matéria. 5 . A tudo isto se acrescenta o impacto da criminalização sobre as mulheres pobres, pois o tratamento como crime, dado pela lei penal brasileira, impede que estas mulheres, 
deste julgamento diz respeito ao fato de que o Habeas Corpus é um procedimento que visa conferir defesa ao direito de liberdade e nada mais; portanto, a matéria sobre a constitucionalidade ou não do aborto sequer poderia ser avençada. Neste caso, em concreto, as provas dos autos não foram elaboradas para requerer a inconstitucionalidade da norma via Habeas Corpus, mas apenas a revogação da prisão preventiva. Mesmo assim, o Ministro Relator elaborou fundamentos de justificação alheios à finalidade do pedido.

Ademais, não se pode falar em inconstitucionalidade da norma que proíbe o aborto prevista no Código Penal, já que se trata de lei infraconstitucional anterior à Constituição Federal e isso é matéria de recepção do direito e não de inconstitucionalidade. Mas, mesmo assim, o julgador decidiu discorrer sobre a constitucionalidade do dispositivo questionado, elaborando interpretação restritiva contra o direito ao reconhecimento da vida do feto e ampliativa para a defesa do direito da mulher que deseja abortar.

Aventou a decisão, em seu discurso justificativo, parâmetro temporal para a análise do bem jurídico a ser tutelado pelo Direito Penal no crime de aborto, informando que só se pode falar em vida quando há um mínimo de três meses de idade gestacional e, portanto, seria possível através do ativismo judicial decidir quando se dá o início da vida. Neste caso, formulou-se fundamentação para a compreensão do que é vida, contrariando norma expressa do Código Civil ${ }^{8}$ que declara que os direitos do nascituro serão protegidos desde a concepção e a norma do Código Penal que prevê que a interrupção da gravidez é crime ${ }^{9}$, criando, além disso, uma hipótese de aborto sem nenhum filtro legislativo.

Por meio deste julgado prova-se o risco à democracia pelo exercício do ativismo judicial e a necessidade de controle de decisões solipsistas. É importante mencionar que as patologias sociais não vão ser passíveis de correção pelo processo judicial. Rosa (2012) lembra que essa situação se fortifica quando envolve interesses de particulares em conflito, pois são incapazes de reformular todo o agir social Ainda, toda e qualquer fundamentação que se utilize de aspectos metajurídicos para o decidir deve ter substrato de prova para fins de decisão, o que poderia ser feito no processo judicial através do "amicus curiae"10, por exemplo. Dessa forma, para fins de justificar os fundamentos de discriminação apontados pelo magistrado como hábeis a permitir a interpretação de que a norma do aborto não compreende como vida o feto com menos de três meses de gestação.

Não pode o magistrado, sob o pretexto de "fazer justiça", utilizar como fundamento fatos não provados nos autos e, assim, assumir critério irracional para o decidir, alegando que se trata de matéria de argumentação e interpretação, quando na verdade se trata de hipótese de insurgência contra a lei já existente e criação de outra lei para fundamentar o afastamento da norma elaborada pelo Poder Legislativo. $O$ ativismo judicial, neste sentido, caracteriza-se como um exercício de livre conveniência e oportunidade motivada, mas não adstrita à lei. Em entrevista (ROSA, 1980), o Ministro Luiz Fux afirmou que para "fazer valer a Constituição Federal e decidir sobre questões morais e públicas os ministros devem observar os anseios da sociedade"11. Segundo ele, quando a Constituição afirma que todo poder emana do povo e que para o povo ele deve ser exercido ${ }^{12}$, deve-se interpretar que o Poder

que não têm acesso a médicos e clínicas privadas, recorram ao sistema público de saúde para se submeterem aos procedimentos cabíveis. Assim, como consequência, multiplicam-se os casos de automutilação, lesões graves e óbitos. 6 . A tipificação penal viola, também, o princípio da proporcionalidade por motivos que se cumulam: (i) constitui-se medida de duvidosa adequação para proteger o bem jurídico que pretende tutelar (vida do nascituro), por não produzir impacto relevante sobre o número de abortos praticados no país, apenas impedindo que sejam feitos de modo seguro; (ii) a possibilidade do Estado em evitar a ocorrência de abortos por meios mais eficazes e menos lesivos do que a criminalização, tais como educação sexual, distribuição de contraceptivos e amparo à mulher que deseja ter o filho, mas se encontra em condições adversas; (iii) a medida desproporcional em sentido estrito, por gerar custos sociais (problemas de saúde pública e mortes) superiores aos seus benefícios. 7. Anote-se, por derradeiro, que praticamente nenhum país democrático e desenvolvido do mundo trata a interrupção da gestação durante o primeiro trimestre como crime, aí incluídos Estados Unidos, Alemanha, Reino Unido, Canadá, França, Itália, Espanha, Portugal, Holanda e Austrália. 8. Deferimento da ordem de ofício, para afastar a prisão preventiva dos pacientes, estendendo-se a decisão aos corréus.

8 Lei no 10.406 , de 10 de janeiro de 2002. Código Civil. Art. $2^{\circ}$ A personalidade civil da pessoa começa do nascimento com vida; mas a lei põe a salvo, desde a concepção, os direitos do nascituro.

9 Decreto-lei no 2.848, de 7 de dezembro de 1940. Código Penal. Aborto provocado pela gestante ou com seu consentimento. Art. 124 - Provocar aborto em si mesma ou consentir que outrem lho provoque: (Vide ADPF 54)Pena - detenção, de um a três anos. Aborto provocado por terceiro Art. 125 - Provocar aborto, sem o consentimento da gestante: Pena - reclusão, de três a dez anos. Art. 126 - Provocar aborto com o consentimento da gestante: (Vide ADPF 54) Pena - reclusão, de um a quatro anos. Parágrafo único. Aplica-se a pena do artigo anterior, se a gestante não é maior de quatorze anos, ou é alienada ou debil mental, ou se o consentimento é obtido mediante fraude, grave ameaça ou violência.

10 Amicus curiae é um termo derivado do latim que significa, de maneira, literal, "amigo da corte" e no processo judicial poderá ser uma pessoa natural ou jurídica, órgão ou entidade especializada, com representatividade adequada, que será ouvida para tratar sobre demanda cuja repercussão social da controvérsia permita e entenda relevante a sua participação (art. 138 do CPC).

11 Agência Brasil. Decisões do STF têm de refletir "anseios da sociedade", afirma Fux. Publicado em 02/10/2018 por Felipe Pontes - Repórter da Agência Brasil - Brasília. O discurso aconteceu durante solenidade em comemoração aos 30 anos da Constituição na sede do Conselho Federal da Ordem dos Advogados do Brasil (OAB), em Brasília. Disponível em: https://agenciabrasil.ebc.com.br/justica/noticia/2018-10/decisoes-do-stf-temde-refletir-anseios-da-sociedade-afirma-fux.

12 Art. $1^{\circ}$, parágrafo único, da $\mathrm{CF} / 88$. 
Judiciário não precisa fazer uma pesquisa de opinião pública para decidir, mas que, quando estão em jogo razões morais e de ordem pública, os ministros do Supremo Tribunal Federal - STF - deverão tomar uma decisão que represente o anseio da sociedade em relação à justiça.

Observe-se que o parâmetro para fins de decisão, segundo o referido ministro, são razões morais e públicas, ao passo que a justificativa para o controle dessas razões é a justiça. Contudo, há dois problemas nessa afirmação: i) a moral não é objetiva, mas subjetiva e, por essa razão, a índole que a expressa diverge de pessoa para pessoa; e ii) no mesmo diapasão, e em que pese tenha desdobramentos circunstanciais de acordo com o julgador, a justiça como justificativa de controle, segundo Maccormick (2010), pode ter parâmetros de alcance cuja interpretação possa aferir resultados distintos porque são ilógicos e não razoáveis.

A entrevista feita com o Ministro Luiz Fux revela-se importante para demonstrar que o Poder Judiciário brasileiro atualmente está enfrentando uma crise já anunciada no direito. Ferrajoli (2018) afirma que a dificuldade encontrada pelo julgador de obedecer à lei é a chamada crise da legalidade. Veja-se que o fundamento inicial da legitimação do Poder Judiciário é a justiça, mas deve-se observar um parâmetro, no caso do Brasil, à Constituição Federal.

Entendendo-se, por essa razão, que os sentidos de seus dispositivos devem ser aplicados de forma coerente e consistente, sem que o casuísmo opere com técnicas de interpretação e argumentação não provadas e, assim, avulsas e não racionais. Essa obediência segue uma lógica procedimental.

Não deve o Poder Judiciário aderir à crise da legalidade e legitimar-se contra a norma. Com essa defesa não se busca justificar a omissão do Poder Legislativo na promoção de leis cujas finalidades sociais são urgentemente necessárias, muito menos justificar a insuficiência e burocracia do Poder Executivo na prestação de serviços públicos.

Busca-se refletir sobre o agigantamento do Poder Judiciário pela ausência de um Poder Legislativo e de um Poder Executivo eficientes e sobre a consequência desse alargamento do poder do órgão jurisdicional que reitera habitualmente a não obediência à lei e pela liberdade criativa sob a alegação de capacidade de saber o que é ou não justiça social, estabelecendo uma verdadeira crise do direito e da política. Nos dizeres de Teixeira (2012), o ativismo judicial é apenas um dos sintomas mais flagrantes de que as sociedades de massa da era Pós-Moderna não se satisfazem mais com as prestações de serviços públicos e tutela de direitos individuais ainda nos moldes do Estado moderno.

O abuso no exercício de uma função estatal gera a possibilidade de controle por outra, enquanto o mau uso da atividade finalística de um dos poderes constituídos gera deficit de legitimidade democrática. $\mathrm{E}$, assim, não há mais um sistema de freios e contrapesos, mas uma verdadeira compensação de um poder pela avocação da atividade finalística por outro. O poder que uma vez foi dividido começa, então, a incorporar o outro, condensando para si as funções dos demais poderes.

Decidir é a atividade finalística do Poder Judiciário e, pela própria expressão normativa da CF (Art. $5^{\circ}$, inc. XXV), o julgador não pode se negar a julgar com base em ausência de lei. Decidir é o poder-dever do juiz. Por essa razão, o julgador é autorizado a decidir com base em analogia, costumes e outras fontes do direito, mesmo que não exista lei específica para o caso em concreto, desde que o faça de forma provada e fundamentada. Veja-se que o julgador é orientado pelo ordenamento jurídico, para que seja capaz de apresentar decisões hábeis a solucionar casos concretos, sendo o instrumento de concretização do provimento jurisdicional o processo.

\section{A fundamentação como critério de controle do ativismo judicial e revisão do julgamento}

A irracionalidade do e no decidir não pode ser aceita como expressão do Poder Judiciário, pois o direito precisa ser invocado pelas partes e necessita ser tutelado segundo fundamentados jurídicos respaldados pela prova construída no processo. A necessidade de fundamentação das decisões judiciais, que orienta o Poder Judiciário, é vinculada aos dispositivos constitucionais e à prova produzida nos autos. Toda discricionariedade dada à autoridade é limitada pela CF e pelas normas infraconstitucionais.

Gervarsoni e Leal (2013) afirmam que a Constituição Federal exige da jurisdição uma postura diferente, que garanta a segurança jurídica das normas e que atenda à complexidade das relações sociais sem subverter o devido processo legal para a proteção de direitos. Segundo Rosa, a Teoria do Garantismo (2012), neste contexto, busca-se resgatar o valor da Constituição, centralizando-a como norteador vinculante de todo o ordenamento jurídico. O resgate da sua valorização é necessário para que se possa estabilizar as normas jurídicas, conferindo a segurança jurídica necessária para a aplicação coerente do direito 
Ao passo que a verdade dos autos é provada somente pelas provas com fundamentação congruente e consistente expressa na CF, permite-se que fundamentos judiciais se utilizem de aspectos sociais não provados estabelecidos em um contexto do caso concreto a partir de uma ideologia de senso individual. Reforçando este argumento, Costa (2013) afirma que não há mais espaço no Estado pós-moderno e globalizado, cuja característica é a pluralidade de pensamentos, de se estabelecer um sistema global de interpretação do mundo como se fosse o único e como uma verdade incontestável.

Ainda que se mencione que o ativismo judicial possa ser resultante de uma letargia do Poder Legislativo, mencione-se também que este, sozinho, nunca será capaz de formar um sistema coerente e completo, em que não haja qualquer falha ou brecha capaz de invocar a atividade criativa do juízo. Nestes casos há um complemento necessário entre o Poder Legislativo e o Poder Judiciário, um elo entre o abstrato e o concreto que precisa ser respeitado. Contudo, Maccormick (2010) já explica que a criatividade do juízo é a liberdade para decidir segundo as determinações da Constituição Federal - CF - quando não existe lei para o caso em concreto. Quando existe lei, aplica-se a lei.

Um aspecto fundamental do ativismo judicial é entender que este só existe quando o juiz quer decidir sem provar o que decidiu, seja rechaçando a existência de lei positivada que pode ser aplicada ao caso concreto, ou pelo método de inovação legislativa para regular o caso em concreto da maneira que lhe convém, mesmo quando contrária às provas dos autos e as orientações da norma. Assim, é possível superar a discricionariedade judicial do decidir não aceitando concepções morais, políticas ou de outra ordem manifestadas pelo juízo ${ }^{13}$. (TEIXEIRA; RADKE, 2017).

A maleabilidade do raciocínio jurídico, desde que dentro dos limites da norma, por outro lado, não é ativismo judicial. Não se busca com o controle do ativismo judicial reduzir a capacidade de interpretação ou argumentação jurídica do juízo, mas sim exigir que o julgador decida racionalmente, amparado em lei e de acordo com a prova fornecida nos autos.

O Poder Judiciário, sem usurpar as funções do Poder Legislativo, tem função atípica para criar a lei do caso em concreto quando este último não o fizer ou o fizer de forma insuficiente. Vale lembrar que a finalidade do Poder Judiciário é fazer justiça, mas o procedimento para concretizá-lo é através do ordenamento jurídico. O juiz deve se permitir criar dentro da lei, assim como qualquer outra autoridade incumbida de alcançar finalidades sociais.

No mesmo passo invocar o Poder Judiciário para resolver conflitos e satisfazer direitos é quase que um chamado social de que algo não está bem, e quando isso ocorre reiteradamente sobre o mesmo fato e com o mesmo argumento jurídico, certamente, o que a sociedade avisa por entrelinhas é que ela deseja que tal fato seja regulado pela lei de forma diferente, mas isso não significa dizer que a sociedade deseja que isso seja regulado casuisticamente.

A atividade criativa do juízo sempre será permitida e deve ser sempre estimulada. O pensar do juiz para além da literalidade da lei, mas em sua conformidade, extensão e coesão aos outros dispositivos do ordenamento jurídico, que permitem o alcance do interesse social no caso concreto, é uma atividade essencialmente democrática. Mas para isso existem técnicas de interpretação e a argumentação jurídica. A decisão deve ser lógica e racional e não meramente poética e moral. (TEIXEIRA; RADKE, 2017).

Por essa razão, vislumbra-se como proposta de controle de decisões ativistas uma vez identificadas na fundamentação do decidir que: se o juiz se utilizou de motivos alheios aos dos dispositivos, previstos no ordenamento jurídico brasileiro, ou elaborou fundamentos para o decidir sem que estes estivessem amparados em provas no processo, a possibilidade do afastamento do juiz do caso por razões de parcialidade do juízo, constatando-se ainda a irregularidade em grau máximo da decisão judicial, aplicando-lhe a sanção de nulidade. A partir disso, então, tem-se esta proposta de controle do ativismo judicial.

Ou seja, quando argumentos irracionais forem utilizados como fundamentos para justificar o decidir judicial sob o critério de fazer o que é certo ou justo, esta motivação vinculará o decidir do juízo como prova de sua parcialidade para o caso, constatando-se a violação ao princípio da imparcialidade.

Da mesma forma, quando a autoridade judicial, em procedimento impróprio para o uso da palavra, fundamentar seu decidir com argumentos totalmente alheios ao objeto da causa ao qual foi chamado para julgar, demonstrará a sua parcialidade para o processo.

13 Teixeira, 2017. 
Ainda, quando a fundamentação de uma decisão judicial adotar como certeza uma compreensão de cunho social não provada nos autos, ou seja, quando o juízo definir que é preciso rever a interpretação dada pela norma, baseando sua decisão em aspectos como discriminação social, não adequabilidade da sociedade ao texto positivado, dentre outros, será imperiosa a revisão do decidir.

Por fim, quando a decisão judicial comparar as regras estabelecidas no ordenamento jurídico com regras estrangeiras que não foram recepcionadas pelo Brasil enquanto um argumento de imposição de uma norma estrangeira sobre a norma positivada brasileira, ofendendo, mesmo que indiretamente, a soberania nacional, também haverá prova da parcialidade do juízo para o decidir. O fundamento da soberania que rege a República Federativa do Brasil não pode ser esquecido pelo Poder Judiciário (CF, 1988, Art. $1^{\circ}$ ).

Assim, a autoridade judicial no exercício da função de julgar um processo deve se ater à prova produzida nos autos e aos comandos normativos do ordenamento jurídico. É possível que, academicamente e em entrevistas, os magistrados, nos limites postos pela Lei Orgânica da Magistratura Nacional, verbalizem e escrevam sobre o que acreditam, exigindo uma reflexão do Poder Legislativo sobre as atuais leis do país; contudo, tais limites não podem ser ultrapassados, já que a liberdade de expressão não pode se sobrepujar aos elementos dos autos e aos dispositivos normativos.

A decisão judicial do caso em concreto exige imparcialidade, que só será alcançada com a estrita obediência aos comandos normativos já existentes, sem recortes ou junções para justificar um pensamento que vai de encontro ao que está posto na lei ou na prova dos autos. Para que o decidir seja racional, buscando-se legitimar a decisão do juízo de natureza democrática, a decisão precisa ter fundamenta na lei brasileira e nos elementos probatórios, sem que se externem, portanto, o pensamento moral e social do juiz. Da mesma maneira, toda expressão de cunho solipsista, que não tiver sido provada durante o processo, poderá ser utilizada para fins de revisão da decisão judicial e afastamento do juiz para o caso, como corolário do devido processo legal e manutenção do dever de imparcialidade do juízo, manifestado no já mencionado princípio do juiz natural.

\section{Considerações finais}

Não se pretende, com o controle do ativismo judicial, que o juiz retorne ao antigo conceito de que o juiz é apenas a boca da lei. Contudo, visa-se confirmar que o julgador, em que pese, tenha discricionariedade no decidir motivado, fazendo-o dentro dos limites da lei e das provas produzidas no processo. Paralisar a forma de pensar do Poder Judiciário não é produzir justiça. A mudança faz parte da ciência social. Contudo, é impossível que a lei determine exatamente todos os fatos da vida, que são muito mais dinâmicos que a lei. $O$ que se deseja é limitar a atividade criativa do juízo não amparado em lei e prova nos autos, para que o decidir não seja mero argumento de autoridade.

A externalização de conceitos morais pelo julgador em sua decisão, mesmo que possa parecer humano e, portanto, aceitável, é um risco à democracia sobre a coerência do ordenamento jurídico e o sistema de separação dos poderes. Não se pode relativizar o instrumento de coerção e ação da lei diminuindo seu efeito de acordo com o caso em concreto, com base em justiça pessoal do julgador, pois nunca haveria isonomia. Desconsiderar a existência da lei e a sua regulamentação pelo decidir judicial é afirmar que a lei não tem coercibilidade, pois poderá ser afastada pelo juízo de acordo com sua conveniência e oportunidade.

Certo é que a valorização do Poder Judiciário e seu espectro de grandeza para correção dos problemas sociais só foi possível de ser alcançado através da omissão dos demais poderes em suas atividades democráticas, mas isso não significa dizer que essa assunção de funções legislativas pelo Poder Judiciário seja correta. $\mathrm{O}$ ativismo é pura expressão de incorporação de poder.

Quando não se controla, mas somente se incorpora o poder em detrimento do outro, o que ocorre é a unificação de mais de um poder dentro de um só. Esta incorporação retoma a concepção de poder único e monopolizado que não é interessante para nenhuma sociedade que se diz democrática. O controle do poder, em que a atividade fim é fiscalizada momentaneamente com a finalidade de se evitar que abusos sejam cometidos - seja por omissão, seja por ação -, não se confunde com a assimilação do poder, em razão de uma permanente omissão da função finalística do Poder ao atender as demandas sociais de forma satisfatória.

É imprescindível que o Poder Legislativo consiga se reorganizar para cumprir a sua função típica de forma satisfatória. Ao passo que, enquanto isso não acontece, sugere-se como uma proposta de controle do ativismo 
judicial, a possibilidade de revisão de decisões judiciais toda vez que os fundamentos e motivações expressos na decisão forem contrários à lei ou apresentem fundamentos não provados no processo ou que não sejam objeto de análise nos autos.

Neste sentido, exercer o devido controle sobre decisões judiciais ativistas reassegurará a separação dos poderes, primando pela segurança jurídica estabelecida pelo ordenamento legal. O método para a controle da decisão judicial ativista será, portanto, identificar os fundamentos expostos nas decisões que estejam alheios às provas produzidas nos autos e sem qualquer respaldo legal.

O decidir irracional será o decidir não legal e não provado, porém que mesmo assim é utilizado como um tipo de senso individualizado do juiz de justiça e que por estar exposto na decisão é um fator indicativo de interferência na imparcialidade judicial e que ensejará na revisão pelo órgão jurisdicional superior para anulabilidade da decisão.

\section{Referências}

ABBOUD, Georges; LUNELLI, Guilherme. Ativismo judicial e instrumentalidade do processo: diálogos entre discricionariedade e democracia. Revista de Processo, São Paulo, v. 242, ano 40, p. 19-45, abr. 2015.

BARBOZA, Estefânia Maria de Queiroz. Jurisdição constitucional, direitos fundamentais e democracia. In: CLĖVE, Clèmerson Merlin; SARLET, Ingo Wolfgang; PAGLIARINE, Alexandre Coutinho (org.). Direitos humanos e democracia. Rio de Janeiro: Forense, 2007. p. 277-293.

BARROSO, Luís Roberto (org.). A reconstrução democrática do direito público no Brasil. Rio de Janeiro: Renovar, 2007.

BONAVIDES, Paulo. Jurisdição constitucional e legitimidade (algumas observações sobre o Brasil). Estudos Avançados, São Paulo, v. 18, n. 51, p. 127-150, 2004. DOI: http://dx.doi.org/10.1590/S010340142004000200007. Disponível em: http://www.scielo.br/scielo.php?script=sci_arttext\&pid=S0103$40142004000200007 \&$ Ing=en\&nrm=iso. Acesso em: 19 nov. 2018.

BRASIL. [Constituição (1988)]. Constituição da República Federativa do Brasil. Brasília, DF: Presidência da República, [2018]. Disponível em: http://www.planalto.gov.br/ccivil_03/constituicao/constituicaocompilado.htm. Acesso em: 21 set. 2018.

BRASIL. Tribunal de Justiça do Rio Grande do Sul. Apelação Criminal 70073021917. Apelação crime. Estupro de vulnerável. Relativização da vulnerabilidade [...]. Relatora: Des. Vanderlei Teresinha Tremeia Kubiak, 27 de setembro de 2017. Disponível em: https://tj-rs.jusbrasil.com.br/jurisprudencia/506956533/apelacao-crime-acr70073021917-rs. Acesso em: 12 nov. 2018.

BRASIL. Decreto-lei 2.848, de 7 de dezembro de 1940. Código Penal. Brasília, DF: Presidência da República, [2018]. Disponível em: http://www.planalto.gov.br/ccivil_03/decreto-lei/del2848.htm. Acesso em: 30 out. 2018.

BRASIL. Supremo Tribunal Federal (1. Turma). Habeas Corpus 124.306/RJ. Direito processual penal. Habeas corpus. Prisão preventiva. Ausência dos requisitos para sua decretação. Inconstitucionalidade da incidência do tipo penal do aborto no caso de interrupção voluntária da gestação no primeiro trimestre. Ordem concedida de ofício. Relator: Min. Marco Aurélio, 09 de agosto de 2016. Disponível em: http://www.stf.jus.br/arquivo/cms/ noticiaNoticiaStf/anexo/HC124306LRB.pdf. Acesso em: 10 set. 2018.

BRASIL. Lei $\mathbf{n}^{\circ}$ 10.406, de 10 de janeiro de 2002. Código Civil. Brasília, DF: Presidência da República, [2018]. Disponivel em: http://www.planalto.gov.br/ccivil_03/leis/2002/l10406.htm. Acesso em: 20 ago. 2018.

BRASIL. Lei no 13.105, de 16 de março de 2021. Código de Processo Civil. Brasília, DF: Presidência da República, [2021]. Disponível em: http://www.planalto.gov.br/ccivil_03/_ato2015-2018/2015/lei//13105.htm. Acesso em: 31 ago. 2021.

CASTRO, Thamis Dalsenter Viveiros de. O papel criativo do juiz na legalidade civil-constitucional. Revista Pensar, Fortaleza, v. 21, n. 2, p. 721-750, maio/ago. 2016. Disponível em: file://C:/Users/ruthi/AppData/Local/ Packages/Microsoft.MicrosoftEdge_8wekyb3d8bbwe/TempState/Downloads/3948-22066-1-PB\%20(1).pdf. Acesso em: 29 maio 2018. 
COSTA, Eduardo José da Fonseca. Uma espetroscopia ideológica do debate entre garantismo e ativismo. In: DIDIER JÚNIOR, Fredie; NALINI, José Renato; RAMOS, Glauco Gumerato; LEVY, Wilson (coord.). Ativismo judicial e garantismo processual. Salvador: Jus Podivm, 2013. p. 171-186.

FERRAJOLI, Luigi. El derecho como sistema de garantias. Revista Jueces para la Democracia, Madrid, $\mathrm{n}$. 16-17, p. 119-130, 1992. Disponível em: https://dialnet.unirioja.es/descarga/articulo/5109886.pdf. Acesso em: 10 set. 2018.

GARAPON, Antoine. 0 juiz e a democracia: o guardião das promessas. Tradução: Maria Luiza de Carvalho. Rio de Janeiro: Editora Revan, 2001.

GERVARSONI, Tássia Aparecida; LEAL, Mônia Clarissa Hennig. Ativismo judicial? O "antes" e o "depois" da Constituição de 1988 na jurisprudência do Supremo Tribunal Federal: um estudo a partir da noção de vinculação dos particulares aos direitos fundamentais. Pensar, Fortaleza, v. 18, n. 3, p. 953-970, set./dez. 2013. Disponível em: https://periodicos.unifor.br/rpen/article/view/2815. Acesso em: 29 nov. 2018.

HABERMAS, Jürgen. Direito e democracia: entre facticidade e validade. Tradução: Flávio Beno Siebeneichler. Rio de Janeiro: Tempo Brasileiro, 1997. v. 2.

HOBBES, Thomas. Leviatã, ou matéria, forma e poder de um Estado eclesiástico e civil. 2. ed. São Paulo: Editora Martin Claret, 2012.

JORGE NETO, Nagibe de Melo. Ativismo judicial, discricionariedade e controle: uma questão hermenêutica? Quaestio luris, Rio de Janeiro, v. 7, n. 2, p. 509-532, 2014.

KOERNER, Andrei. Ativismo Judicial?: jurisprudência constitucional e política no STF pós-88. Novos estudos CEBRAP, São Paulo, n.96, p. 69-85, jul. 2013. DOI: http://dx.doi.org/10.1590/S0101-33002013000200006. Disponível em: http://www.scielo.br/scielo.php?script=sci_arttext\&pid=S0101-33002013000200006\&lng=en\&nrm =iso. Acesso em: 29 nov. 2018.

LIMA, F. D. S. Perdedores no Congresso Nacional e no STF? A judicialização das questões interna corporis do legislativo. Revista Jurídica da Presidência, Brasília, v. 18, n. 115, p. 307-330, jun./set. 2016.

MACCORMICK, Neil. Argumentación e interpretación en el derecho. DOXA Cuadernos de Filosofía del Derecho, Alicante, n. 33, p. 65-78, 2010. Disponível em: http://rua.ua.es/dspace/bitstream/10045/32593/1/ Doxa_33_04.pdf. Acesso em: 03 out. 2018.

MARQUES, Leonardo Augusto Marinho. O modelo constitucional de processo e o eixo estrutural da processualidade democrática. Revista Brasileira de Direito Processual Penal, Porto Alegre, v. 2, n. 1, p. 4355, 2016. Disponível em: http://www.ibraspp.com.br/revista/index.php/RBDPP/article/view/16/37. Acesso em: 29 nov. 2018.

MONTESQUIEU. O espírito das leis: as formas de governo, a federação, a divisão dos poderes, presidencialismo versus parlamentarismo. Tradução: Pedro Vieira Mota. 3. ed. São Paulo: Saraiva, 1994.

NEVES, Daniel Amorim Assumpção. Novo código de processo civil comentado. 3. ed. Salvador: Editora Juspodivm, 2018.

NUNES, Dierle. Processualismo constitucional democrático e o dimensionamento de técnicas para a litigiosidade repetitiva. Revista de Processo, São Paulo, n. 199, p. 41-83, set. 2011.

OLIVEIRA NETO, Francisco José Rodrigues de. A estrita legalidade como limitador democrático da atividade judicial. Pensar, Fortaleza, v. 16, n. 2, p. 527-561, jul./dez. 2011.

PICÓ I JUNOY, Juan. El derecho procesal entre el garantismo y la eficácia: um debate mal planteado.

Derecho y Sociedad, Lima, n. 38, p. 274-280, 2012. Disponível em: http://revistas.pucp.edu.pe/index.php/ derechoysociedad/article/view/13126. Acesso em: 29 ago. 2018. 
RODRIGUES, Paulo Gustavo. A convicção contextualizada e a verdade negociada no processo penal: desmistificando a confissão como elemento de convencimento pleno do julgador penal. Revista Brasileira de Direito Processual Penal, Porto Alegre, v. 3, n. 1, p. 103-130, 2017. Disponível em: file:///C:/Users/ruthi/ AppData/Local/Packages/Microsoft.MicrosoftEdge_8wekyb3d8bbwe/TempState/Downloads/32-206-1-PB\%20 (1).pdf. Acesso em: 29 nov. 2018.

ROSA, Alexandre Morais da. Por uma leitura garantista do sistema de controle social. In: GAVAZZONI, Antonio Marcos; MARCELINO JUNIOR, Julio Cesar (org.). Constituição Estado e garantismo jurídico: diálogos cruzados. São Paulo: Editorial Conceito, 2012. p. 109-124.

ROSA, Felipe A. de Mirando. Patologia social: uma introdução ao estado da desorganização social. 5. ed. Rio de Janeiro: Zahar Editores, 1980.

STRECK, Lenio Luiz. O direito brasileiro atravessado pelo julgamento do Mensalão: do livre convencimento aos dilemas da continuidade do positivismo. Revista dos Tribunais, São Paulo, n. 933, p. 297-315, jul. 2013.

STRECK, Lenio Luiz. O que é isto - decido conforme minha consciência? 4. ed. Porto Alegre: Livraria do Advogado, 2013.

TEIXEIRA, Anderson V. Ativismo judicial: nos limites entre racionalidade jurídica e decisão política. Revista Direito GV, São Paulo, v.8, n. 1, p. 37-58, jan./jun. 2012.

TEIXEIRA, A. V.; RADKE, R. W. Habermas e a tentativa procedimental de superação da discricionariedade judicial. Revista Brasileira de Estudos Políticos, Belo Horizonte, n. 115, p. 81-108, jul./dez. 2017.

UNITED STATES OF AMERICA. Lochner v. New York, 198 U.S. 45 (1905): Justia opinion summary and annotations. JUSTIA US Supreme Court, New York, v. 198. Disponível em: https://supreme.justia.com/cases/ federal/us/198/45/. Acesso em: 10 nov. 2018.

Recebido em: 06.08 .2020

Aceito em: 16.08 .2021 